\title{
Multilayered amniotic membrane transplantation in a case of chronic corneal fistula
}

\author{
Raghav Preetam Peraka, Paavan Kalra
}

The Cornea Institute, L V Prasad Eye Institute, Hyderabad, India

\section{Correspondence to \\ Dr Paavan Kalra;}

paavan@lvpei.org

Accepted 13 August 2020

\section{DESCRIPTION}

A 19-year old man with a peripheral corneal scar in left eye (LE) status post microbial keratitis 1 year ago developed perforation at the site of the scar after a recent injury with a finger. Cyanoacrylate tissue adhesive (TA) application with bandage contact lens (BCL) placement was done locally prior to referral to us. On examination, visual acuity in LE was 20/100 (20/50 with pinhole). TA was dislodged from its place and circular perforation of size 1-2 mm close to the limbus at 8 o'clock, with surrounding vascularised scar and irregular anterior chamber (AC) depth were noted (figure $1 \mathrm{~A}$ ). The right eye (RE) was within normal limits. TA BCL application with AC reformation was done in LE. Six weeks later, he had to undergo repeat procedure for a similar situation. Subsequently, AC remained well formed for the next 3 months when it was decided to remove TA in the operating room. After removal of TA, unhealed perforation with punched-out edges was noted underneath. The epithelium surrounding the perforation was removed. An amniotic membrane folded on itself three times was used to cover the perforation and was secured to the cornea with 10-0 nylon overlay sutures (multilayered amniotic membrane graft (mAMG)) (figure 1B,C). Fibrin glue was used in between layers of amniotic membrane. AC was formed with saline and small air bubble and a BCL was placed. On postoperative day 1 , he required replacement of one loose suture. He received a prophylactic antibiotic and lubricating eye drops postoperatively. Subsequently over next

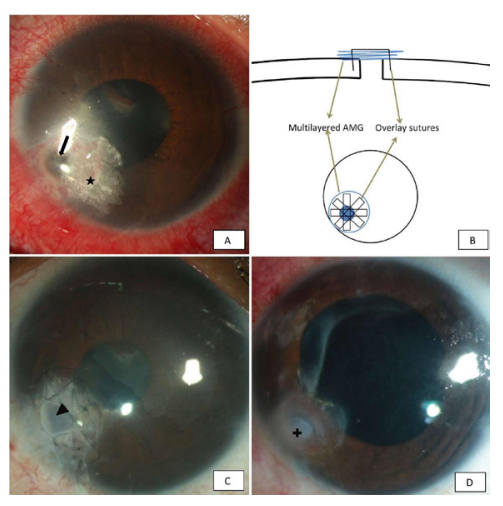

Figure 1 (A) Corneal perforation (arrow) with dislodged TA (star) and adjacent vascular scar. (B) Technique of mAMG with overlay sutures (illustrative diagram). (C) 1 week postoperation: mAMG with overlay sutures showing ballooning over area of peroration (arrowhead). (D) After 1 year: healed perforation with integrated amniotic membrane (plus). mAMG, multilayered amniotic membrane graft; $T A$, tissue adhesive.

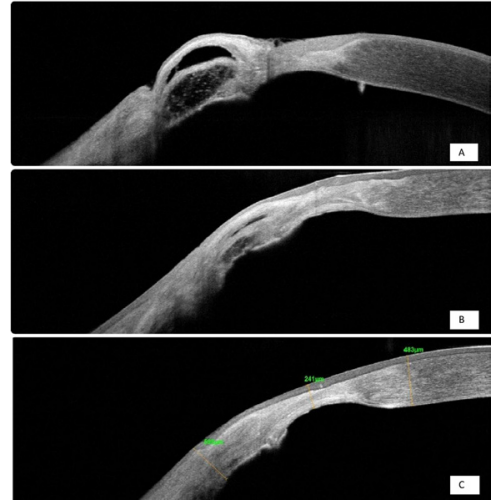

Figure 2 Serial anterior segment optical coherence tomography scans showing progressive integration of multilayered amniotic membrane graft into the corneal stroma closing the chronic fistula. Postoperative duration (A) 6 weeks, (B) 4 months and (C) 7 months.

6 months, sutures were removed and the amniotic membrane became integrated within the stroma. $\mathrm{He}$ underwent left eye lens aspiration with posterior chamber intraocular lenses (PC IOL) implantation for complicated cataract 10 months after mAMG (figure 1D). Best-corrected visual acuity 6 months after cataract surgery was $20 / 20$ p. Serial anterior segment optical coherence tomography (AS-OCT) scans over a 7-month period shows a relatively hyper-reflective signal in the healed region of a previous fistula, indicating integration of multilayered amniotic membrane into corneal stroma (figure $2 \mathrm{~A}-\mathrm{C}$ )

A corneal fistula is a communication between the $\mathrm{AC}$ and the corneal surface. ${ }^{1}$ Corneal fistula follows either trauma or perforation in corneal ulcer, infected or sterile. The defect does not heal spontaneously because of the combined poor tissue apposition and persistent aqueous humour flow. ${ }^{1}$ Persistence of perforation can lead to potentially devastating complications like peripheral anterior synechiae formation, secondary glaucoma, prolonged or recurrent hypotony, phthisis bulbi, endophthalmitis or panophthalmitis. The management of a corneal perforation includes tissue glues, mAMGs, Tenon's patch and tectonic corneal grafts, depending on the size, shape, location, cause of the lesion, the surgeon's experience and the availability of tissue. ${ }^{23}$ Amniotic membrane transplantation, if used for corneal perforation, can prevent urgent penetrating keratoplasty. Its application can restore stromal thickness and its advantage is that it can be stored in appropriate conditions for many months. Various authors have reported good final functional 
result following use of the multilayered amniotic membrane transplantation. ${ }^{45}$ The limitation of using AMG is that it is an opaque tissue. Thus, in patients with perforation involving the centre of the cornea, visual acuity may not improve in spite of adequate healing.

\section{Learning points}

Multilayer amniotic membrane transplantation is an effective method for the treatment corneal perforations.

- The biological properties of amniotic membrane make it a useful tool for the reconstruction of damaged corneal tissue to restore its integrity.

Acknowledgements I thank my institute, L V Prasad Eye Institute, which has given me the foundation for making this report.
Contributors RPP and PK were involved in creating the content and organising the images of this report. RPP conceptualised the paper. PK managed the patient and also acquired the images. PK is the overall guarantor of the paper.

Funding Hyderabad Eye Research Foundation, India.

Competing interests None declared.

Patient consent for publication Obtained.

Provenance and peer review Not commissioned; externally peer reviewed.

\section{REFERENCES}

1 Mannis MJ, Ruben J, Wedemeyer L. Corneal fistulas and their management. Am J Ophthalmol 1988; 105:626-31.

2 Singhal D, Sahay P, Maharana PK, et al. Clinical presentation and management of corneal fistula. Br J Ophthalmol 2019;103:530-3.

3 Jhanji V, Young AL, Mehta JS, et al. Management of corneal perforation. Surv Ophthalmol 2011;56:522-38.

4 Hick S, Demers PE, Brunette I, et al. Amniotic membrane transplantation and fibrin glue in the management of corneal ulcers and perforations: a review of 33 cases. Cornea 2005:24:369-77.

5 Kim HK, Park HS. Fibrin glue-assisted augmented amniotic membrane transplantation for the treatment of large noninfectious corneal perforations. Cornea 2009;28:170-6.

Copyright 2020 BMJ Publishing Group. All rights reserved. For permission to reuse any of this content visit https://www.bmj.com/company/products-services/rights-and-licensing/permissions/

BMJ Case Report Fellows may re-use this article for personal use and teaching without any further permission.

Become a Fellow of BMJ Case Reports today and you can:

- Submit as many cases as you like

- Enjoy fast sympathetic peer review and rapid publication of accepted articles

- Access all the published articles

- Re-use any of the published material for personal use and teaching without further permission

\section{Customer Service}

If you have any further queries about your subscription, please contact our customer services team on +44 (0) 2071111105 or via email at support@bmj.com.

Visit casereports.bmj.com for more articles like this and to become a Fellow 